\title{
Performance and scientific contributions of the Research Group “Integrated Urban Water Management" of the State University of Maringá, Paraná State, Brazil
}

\author{
Atuação e contribuições científicas do Grupo de Pesquisa "Gestão \\ Integrada de Águas Urbanas" da Universidade Estadual de Maringá, \\ Paraná, Brasil
}

\begin{abstract}
Cristhiane Michiko Passos Okawa '; Ana Carla Fernandes Gasques "; Cássia Rocha Pompeu III; Paula Polastri IV; Priscila Pini Pereira v; Bruno Henrique Toná Juliani VI; Juliane Vier Vieira VII
\end{abstract}

\begin{abstract}
Research Group Integrated Urban Water Manegement (GIAU) was founded in 2014, due to the need to study and to suggest solutions to weaknesses reported in the municipality of Maringá, in Paraná State, regarding this subject. The integrated urban water management comprehend ah holistic view to potable water supply and sanitary sewage systems, water drainage management in urban areas, besides urban solid waste management. In this context, the aim of this paper is to present the research group and its main contributions up to this point. The applied method consisted in present the history from creation, formation and recent actions of the whole group and in realize a systematic review of the published papers. The main results showed that although recent, the group has worked in a proactive way in its community by means of promotion of lectures and events, besides the production of 52 publications in national and international journals, national and international events, books and book chapters. The group has also board members highly qualified, concentrating in the training of human resources. It can be concluded that the research group is consolidating, with high performance expectations.
\end{abstract}

Keywords: Urban water monitoring; Urban water resources management; Valley floors and urban rivers

\footnotetext{
' Universidade Estadual de Maringá, Maringá, Brazil. cmpokawa@uem.br

" Universidade de São Paulo, São Carlos, Brazil. anacarlafgasques@gmail.com

III Universidad de Cantabria, Santander, Spain. cassia.pompeu@gmail.com

IV Universidade Estadual de Maringá, Maringá, Brasil. paula_pol@hotmail.com

v Universidade Tecnológica Federal do Paraná, Apucarana, Brazil. priscilapereira@utfpr.edu.br

vı Universidade Federal do Paraná, Curitiba, Brazil. brunotjuliani@gmail.com

VII Faculdade de Engenharia e Inovação Técnico-Profissional, Maringá, Brazil. prof.juliane@feitep.edu.br
} 


\section{RESUMO}

O Grupo de Pesquisa em Gestão Integrada de Águas Urbanas (GIAU) foi criado em 2014, face à necessidade de estudar e propor soluções para as deficiências constatadas no município de Maringá, no estado do Paraná, com relação a este tema. A gestão integrada das águas urbanas compreende uma visão holística para os sistemas de abastecimento de água potável e de esgotamento sanitário, manejo de águas pluviais urbanas e seu sistema de drenagem urbana, além da gestão dos resíduos sólidos urbanos. Neste contexto, o objetivo deste artigo é apresentar o grupo de pesquisa e suas principais contribuições. O método utilizado foi apresentar o histórico da criação, a formação e atuação do grupo de pesquisa e realizar uma revisão sistemática de seus artigos publicados. Os principais resultados encontrados mostraram que o grupo de pesquisa, embora bastante novo, tem atuado de maneira pró-ativa em sua comunidade por meio da ministração de palestras e promoção de eventos, além de produzir 52 publicações distribuídas em periódicos nacionais e internacionais, eventos nacionais e internacionais, livro e capítulos de livros. O grupo possui ainda um quadro de membros altamente qualificado, que se concentra na formação de recursos humanos. Conclui-se que o grupo de pesquisa, embora novo, tem se consolidado e que suas expectativas de atuação são boas, sendo que a próxima meta é a instituição de parcerias internacionais.

Palavras-chave: Monitoramento de águas urbanas; Gestão de recursos hídricos urbanos; Fundos de vale e rios urbanos

\section{INTRODUCTION}

For the construction of cities, the land is impermeabilized when the forests give their place to streets, sidewalks, edifications, among other buildings (TUCCl, 2007). Besides this, the agglomeration of people leads to even more pollution, due to solid waste and garbage generated by population, sanitary sewage, difuse pollution in storm water galleries and also oil and grease derived by vehicles, that when in contact with water bodies, cause the deterioration of water quality (McGRANE, 2016; PEÑAGUZMÁN; MELGAREJO; LOPEZ-ORTIZ, 2017; BRANDELER, GUPTA, HORDIJK, 2019).

Another important factor is the way that the municipal management defines the territorial management, with specific zoning and land use regulations. Pizella (2015) points out the necessity of integration between the Municipal Master Plan and the water resources planning by water basins committees, in a way to contemplate the integrated territorial management and water safety of supply systems. Besides 
the Master Plan, the Municipal Basic Sanitation Plan also considers the water safety at aligning the four lines of basic sanitation: potable water public supply, sanitary sewage system, urban drainage and solid waste. These four lines composing the basic sanitation is called urban waters.

In Brazilian municipalities, the integrated urban water management comprehend the understanding, the administration and public policies to services of potable water supply, sanitary sewage, urban drainage and the gathering, disposal and treatment of solid waste. Historically, the administration of these services is realized in an independent way and by sectors, being this service realized even by the concession to a private company of the rights of determined service (potable water, sewage or solid waste). Besides this, the decision processes are frequently oriented by financial factors or specific interests, which makes it difficult to adopt a more holistic approach in finding integrated and sustainable solutions in urban water management (COLE; SHARVELLE; GRIGG; PIVO; HAUKAAS, 2018). Therefore, the integrated management is not always present in Brazilian municipalities, although being important and necessary.

When the diagnosis of valley floors and urban rivers is realized, it is commonly found evidences of the influence of one system over another one. By example, the inadequate packing of solid domestic waste generates pollution in river channels as far as the solid waste is carried by rainwater, what may impact in public water supply in case of this river being part of a watershed. Likewise, the inadequate disposal of solid waste in valley floors, such as batteries, sofas, tires and construction waste, by a population without environmental sensibilization, results in the deterioration of water quality. This impact is also provoked by clandestine launches of non-treated sanitary sewage, directly in river channels, by industries or residences.

Many researchers have been studying the integrated urban water management in different approaches: Silva, Souza Filho, Cid, de Aquino e Xavier (2019) used an integrated urban water management model as an strategic tool to the promotion of water safety and in preparation for drought events in the city of Fortaleza, in northeast Brazil; Brandeler, Gupta and Hordjik (2019) liked the integrated urban water 
management with the municipal management of urban water basins in megacities and concluded that this relationship has too little attention in academic discussions and public policies debates; Koop and Van Leeuwen (2015) enhanced the City Blueprint Framework, instrument composed by indicators that evaluate the integrated urban water management and applied it in 45 municipalities in 27 countries, in order to validate this modification in the tool, obtaining better results in the evaluation the performance of the cities; Jalilov, Kefi, Kumar, Masago e Mishra (2018) covered water, sewage and urban drainage integrated systems in order to implement the project Water and Urban Initiative in 3 cities in southeast Asia, to evaluate urban floods in the following criteria: damage provoked, human health risks and improvements in water quality due to flood control. An important observation regarding this study is that nonstructural measures, such flood risk analysis and mapping, may be highly effective in territorial land use planning and management, highlighting the importance in the integration of urban water management with the territorial management, improving the capacity of the communities to handle floods. Peña-Guzmán, Melgarejo, LopezOrtiz and Mesa (2017) simulated infrastructure options (rainwater use, industrial water reuse, grey water reuse, among others) in two river basins in Bogotá, Colombia, with results that showed possible reduction in consumption of potable water around $40 \%$ and a reduction in wastewater around 20\%. Cole, Sharvelle, Grigg, Pivo and Haukaas (2018) designed a colaborative planning structure of integrated urban water management, using multicriteria analysis concepts to assist the decision making (MCDA). The results of this study confirmed that the use of MCDA facilitates the perception of advantages and disadvantages of each of the considered alternatives, providing a quantitative methodology to compare alternatives with different performance indicators, considering the priorities of the concerned parties in the process.

Based on this approach, and aiming an holistic vision, a research group was founded in order to apply concepts of the Integrated Urban Water Management in municipalities of the state of Paraná, Brazil, promoting social wellbeing, environmental preservation and sustainable development. Another important goal of 
the group is the training of human resources, by means of development of solutions that promote a better comprehension regarding the Urban and Environmental Engineering, involving researchers, professionals and students in research and extention activities. Therefore, the involvement between research institutions, environmental public agencies and municipal public authorities is widely recommended. The means of dissemination of the results of the studies of the group incorporate journals, national events, international events and book chapters, contributing to the training of human resources both in undergraduation and postgraduation students.

The objective of this paper is to present the research group, considering actuation and main scientific and social contributions, such as lectures and promotion of events.

\section{GROUP OVERVIEW}

The research group Gestão Integrada de Águas Urbanas (GIAU, Integrated Urban Water Management) was created on April 3, 2014, embracing five lines of action: 1. Water Resources Management, 2. Potable Water Supply Integrated Management, 3. Wastewater Integrated Management, 4. Solid Waste Integrated Management and 5. Urban Drainage Integrated Management. Although these research lines are specific, the integration of sanitation services processes are inevitable, just as its relation with water resources management, specially those inserted in urban environment.

The current composition of the group is of seven PhDs, eleven masters, three master students with specialization and three undergraduate students who participate in scientific initiation projects, totaling twenty-four people. This composition has changed over the years, which is quite common since undergraduate and post-graduate students cooperate with the group in a temporary action. With regard to academic backgrounds, the components are graduated in Civil Engineering (12), Chemical Engineering (2), Environmental Engineering (5), Architecture and 
Urbanism (1) and Environmental Management Technology (1); the academic research students are enrolled in Civil Engineering graduation. The group members act in one or more or the five research lines.

The major challenge is to develop an holistic perspective among the group participants, as each one has a dominant research area. Given this situation, a periodical meeting called Breakfast Research (Café com Pesquisa) is carried out. Figure 1 shows the participants of the first Breakfast Research meeting, conducted on February 17, 2018. In Breakfast Research, members of each research approach present their studies and have the opportunity to discuss it with other members, in a way to improve the understanding of the influences of one system in the others, besides fostering harmony among the participants, especially in breakfast time. In these meetings, future work and researches are also set out, as well as the definition of the events and journals for publication.

Figure 1 - Participants of the first Breakfast Research meeting in February 17, 2018

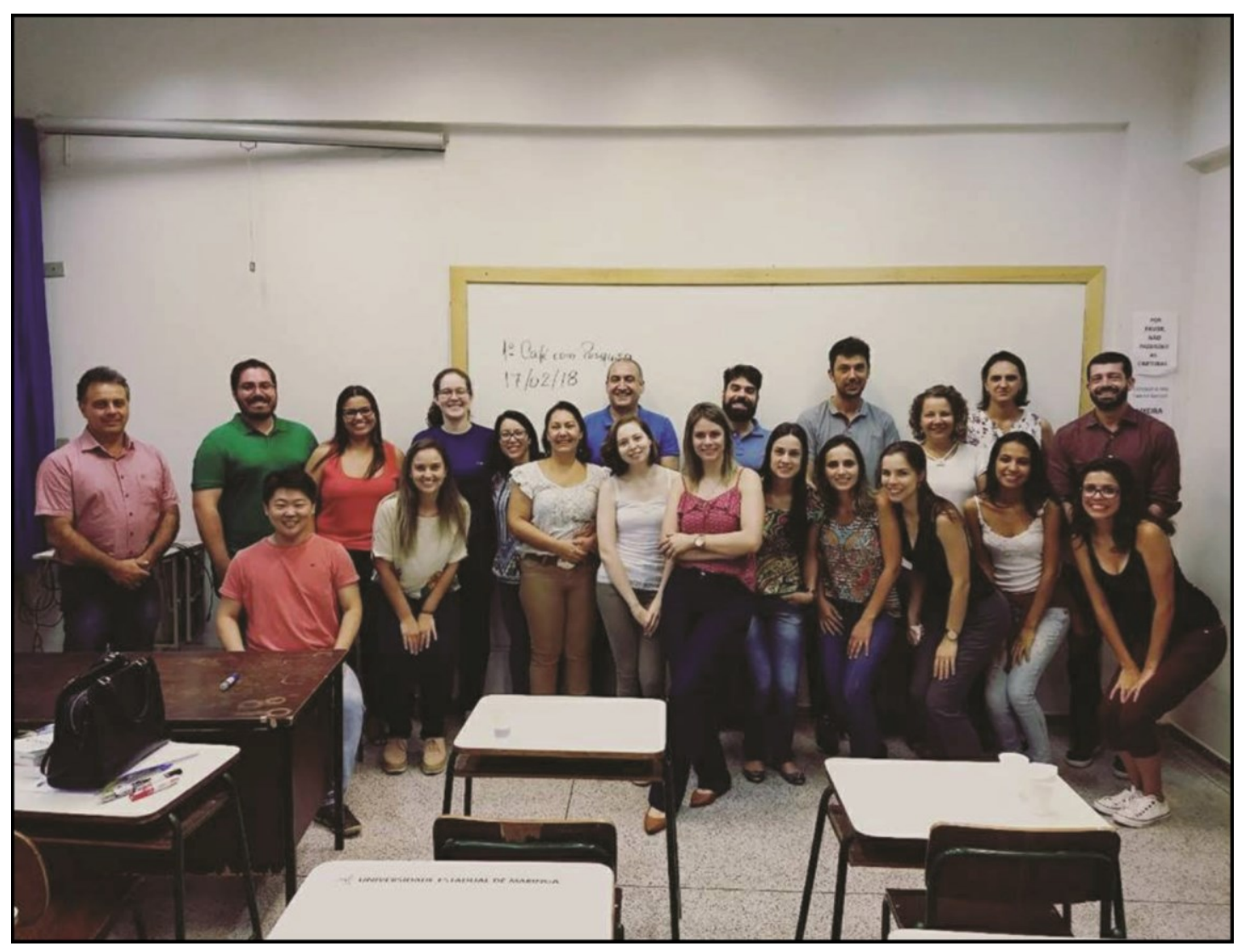


The training of human resources is a key challenge of the group, as undergraduate and post-graduate students usually leave the group after finishing their studies, at the same time as new academics enter in a continuous flow. Therefore, the close relationship between the undergraduate academics with the post-graduate students and with the professors and professionals are healthy and it benefits the whole group. Besides this, many group members work as professors and researchers in different Higher Education Institutions, as the State University of Maringá (UEM), Federal Technologic University of Paraná (UTFPR), TechnicalProfessional Innovation and Engineering Faculty (FEITEP), University Centre of Maringá (UNICESUMAR), University Centre of Adamantina (UniFAl). Part of the members work in the private initiative, even as entrepreneurs. As stated, the group is composed by a wide range of specialists, that besides their academic qualification, the integration with the private initiative labor market provides the association between theorical and practical problems as a start point for researches.

\section{GIAU WORKING ACTIVITIES}

The GIAU has been active in the training of human resources by means of the orientation to scientific initiation, specialization and master students and by means of de paper publications in events and journals. Besides this, the promotion and presentation of lectures and scientific events involve the society in the discussion of the urban water integrated management, regarding not only to listed problems but also to the search for a better solution in a participative management, in order to obtain alternatives with a greater commitment of all parties concerned.

The present topic presents the working activities of group members in lectures, paper production, scientific event promotion and publication of books and book chapters. 


\subsection{Lectures}

Some of the group participants were invited to conduct lectures in several events, such as Engineering Academic Weeks, local and regional events and also in national and international Symposia. In Table 1, it is presented the given lectures and their respective speakers.

Table 1 - Lectures conducted by three GIAU members in a range of events

\begin{tabular}{|c|c|c|c|c|}
\hline Lecturer & Title & Event Coverage & Event Title & Local and Data \\
\hline $\begin{array}{l}\text { Cristhiane } \\
\text { Michiko Passos } \\
\text { Okawa }\end{array}$ & $\begin{array}{l}\text { The Engineer Expertise in } \\
\text { the Water Resources }\end{array}$ & Local & $\begin{array}{l}\text { III Engineering Week, } \\
\text { UNINGÁ }\end{array}$ & $\begin{array}{l}\text { Maringá - PR, } \\
\text { Oct/2014 }\end{array}$ \\
\hline $\begin{array}{l}\text { Cristhiane } \\
\text { Michiko Passos } \\
\text { Okawa }\end{array}$ & $\begin{array}{l}\text { Sustainable Urban } \\
\text { Drainage }\end{array}$ & Local & $\begin{array}{l}\text { Civil Engineering } \\
\text { Academic Week, } \\
\text { UTFPR }\end{array}$ & $\begin{array}{l}\text { Campo Mourão - } \\
\text { PR, Sep/2016 }\end{array}$ \\
\hline $\begin{array}{l}\text { Cristhiane } \\
\text { Michiko Passos } \\
\text { Okawa }\end{array}$ & $\begin{array}{l}\text { Smart Cities in the } \\
\text { sanitation sector }\end{array}$ & Local & $\begin{array}{l}\text { II Engineering and } \\
\text { Architecture Academic } \\
\text { Week, FEITEP }\end{array}$ & $\begin{array}{l}\text { Maringá - PR, } \\
\text { Oct/2016 }\end{array}$ \\
\hline $\begin{array}{l}\text { Cristhiane } \\
\text { Michiko Passos } \\
\text { Okawa }\end{array}$ & $\begin{array}{l}\text { Water Basin Committees: } \\
\text { overcoming challenges in } \\
\text { the water resources } \\
\text { participative management }\end{array}$ & National & $\begin{array}{l}\text { Symposium of } \\
\text { Sustainable Systems }\end{array}$ & $\begin{array}{l}\text { Porto Alegre - RS, } \\
\text { Oct/2016 }\end{array}$ \\
\hline $\begin{array}{l}\text { Cristhiane } \\
\text { Michiko Passos } \\
\text { Okawa }\end{array}$ & $\begin{array}{l}\text { Water Resources } \\
\text { Management: the } \\
\text { Engineer acting in water } \\
\text { basin committees }\end{array}$ & Regional & $\begin{array}{l}\text { IX Technology and } \\
\text { Environmental Week/ I } \\
\text { Environmental } \\
\text { Engineering } \\
\text { Paranaense Meeting }\end{array}$ & $\begin{array}{l}\text { Londrina - PR, } \\
\text { Sep/2017 }\end{array}$ \\
\hline $\begin{array}{l}\text { Cristhiane } \\
\text { Michiko Passos } \\
\text { Okawa }\end{array}$ & $\begin{array}{l}\text { Guidelines of } \\
\text { sustainability for basins } \\
\text { and urban rivers }\end{array}$ & Regional & $\begin{array}{l}\text { Seminar of } \\
\text { Environmental } \\
\text { Policies: conservation } \\
\text { unities, water } \\
\text { resources and } \\
\text { sustainable agriculture }\end{array}$ & $\begin{array}{l}\text { Maringá - PR, } \\
\text { Aug/2019 }\end{array}$ \\
\hline $\begin{array}{l}\text { Ana Paula } \\
\text { Jambers } \\
\text { Scandelai }\end{array}$ & $\begin{array}{l}\text { Efluent advanced } \\
\text { treatment techniques }\end{array}$ & Local & $\begin{array}{l}\text { II Cycle of Lectures of } \\
\text { Environmental } \\
\text { Engineering and } \\
\text { Agronomy, UNIFAI }\end{array}$ & $\begin{array}{l}\text { Adamantina - SP, } \\
\text { Oct/2017 }\end{array}$ \\
\hline $\begin{array}{l}\text { Ana Paula } \\
\text { Jambers } \\
\text { Scandelai }\end{array}$ & $\begin{array}{l}\text { Industrial and Domestic } \\
\text { Efluent treatment } \\
\text { techniques }\end{array}$ & Local & $\begin{array}{l}\text { IV Engineering and } \\
\text { Architecture Academic } \\
\text { Week, FEITEP }\end{array}$ & $\begin{array}{l}\text { Maringá - PR, } \\
\text { Sep/2018 }\end{array}$ \\
\hline
\end{tabular}


Ana Paula Jambers

Scandelai

Basic Sanitation in remote urban and rural areas

International

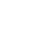

\begin{tabular}{|c|c|c|c|c|}
\hline $\begin{array}{l}\text { Jaqueline Pirão } \\
\text { Zotesso }\end{array}$ & Solid Waste & Local & $\begin{array}{l}\text { II Cycle of Lectures of } \\
\text { Environmental } \\
\text { Engineering and } \\
\text { Agronomy, UNIFAI }\end{array}$ & $\begin{array}{l}\text { Adamantina - SP, } \\
\text { Oct/2017 }\end{array}$ \\
\hline $\begin{array}{l}\text { Jaqueline Pirão } \\
\text { Zotesso }\end{array}$ & $\begin{array}{l}\text { Industrial and Domestic } \\
\text { Efluent treatment } \\
\text { techniques }\end{array}$ & Local & $\begin{array}{l}\text { IV Engineering and } \\
\text { Architecture Academic } \\
\text { Week, FEITEP }\end{array}$ & $\begin{array}{l}\text { Maringá - PR, } \\
\text { Sep/2018 }\end{array}$ \\
\hline $\begin{array}{l}\text { Jaqueline Pirão } \\
\text { Zotesso }\end{array}$ & $\begin{array}{l}\text { The impacts of } \\
\text { inadequate management } \\
\text { of solid waste in urban } \\
\text { waters }\end{array}$ & Regional & $\begin{array}{l}\text { Il Meeting of } \\
\text { Integrated Urban } \\
\text { Water Management, } \\
\text { UTFPR }\end{array}$ & $\begin{array}{l}\text { Apucarana - PR, } \\
\text { Aug/2019 }\end{array}$ \\
\hline
\end{tabular}

It can be noted, in Table 1, a wide range of topics related to urban water management, covering not only basic sanitation services related to urban waters, but also policies regarding this topic, as representation in water basin committees, territorial management in municipalities in the land use and occupation, especially in public water supply basin areas, and also the use of information and communication technologies in urban management along with technological and automated development, already in use in developed smart cities.

\subsection{Published papers in journals, international and national events and}

\section{published books and book chapters:}

The group initiated publishing papers in 2013, although it would only be instituted formally in 2014. The first publications were scientific papers for the IX ENTECA 2013 (Civil Engineering and Architecture Technological Meeting), with five published articles, discussing topics as the characterization and diagnosis of regions with frequent floods in the municipality of Maringá, PR (GASQUES; OKAWA; ANGELIS NETO; ZOLA; SILVA; CASTRO, 2013) and characterization of valley floors inserted in urban area, listing the frequent and repetitive environmental impacts in these 
locations, as well as the inadequate disposal of solid waste and civil construction waste, besides diffuse pollution (ZOLA; GONZALES; KURODA; YANO; ROVERI; OKAWA, 2013), erosion and silting up processes (POMPEU; KURODA; ALBUQUERQUE; FUSINATO; OKAWA, 2013), absence of vegetation in the margins of the river and its implications according to current legislation (RICCIARDI; SOUZA; ROVERI; OKAWA; ISIRI; DUARTE, 2013). Still in 2013, 3 papers were published in the XX Brazilian Symposium of Water Resources, approaching topics as permeable pavements as sustainable urban drainage mechanism (VIEIRA; LAUTENSCHLAGER; ILDEFONSO; OKAWA; JABUR, 2013), determination of reference flow in a public water supply basin, as a study case for Pirapó river in the allowance of water usage grant for effluent disposal (OKAWA; NAGASHIMA; VIEIRA; SOARES; MARQUES; VITAL et al., 2013), and the evaluation of risk flood areas in urban hydrological basin of Fundo stream in Pato Branco, PR (JABUR; DORNELLES; SILVEIRA; GOLDENFUM; CARDOSO; OKAWA, 2013).

Following those publications, the researched group was founded in 2014, in the Research Group Directory of CNPq. In the items 3.2.1 to 3.2.3 the publications for the most recent years are listed.

\subsubsection{Published papers in journals}

The group started exploring valley floors of the city of Maringá, with the first journal publication being the physic characterization of Mandacaru Stream (PEREIRA; BERBERT; SANCHES; MARTINS FILHO; OKAWA; PAREDE et al., 2014).

In 2015, five papers of group members were included in a special edition of REGET, available at https://periodicos.ufsm.br/reget/issue/view/962. The subjects covered were urban drainage in frequent flood areas in Maringá, Paraná; inadequate disposal of solid waste in valley floors; environmental education to raise awareness of children and young people with the conception of an environmental handbook for valley floors; and an analysis of the topographic influence in flood occurrences in the municipality of Maringá, with a surprising result, in which was found that the most frequent flood points occurred in most elevated areas, caused by the sub sizing of urban drainage network, regardless the land topography. 
In 2016, 3 articles were published in journals: one paper in the Journal of Urban and Environmental Engineering, regarding the effluent generated by cement industries (ZOLA; ARAGÃO; ZOLA; OKAWA; ANGELIS NETO, 2016), other paper about the environmental education in two State Colleges in Sarandi, PR (GASQUES; OKAWA; SANTOS; GASQUES; DELABIO, 2016) and one article with the analysis of the use and occupation of the land in the Maringá Creek over the years, presenting the increase in the speed and volume of surface runoff (VALLE; POMPEU; RICCIARDI; OKAWA; MARTINS; PAREDES, 2016).

In 2018 a paper was published in the journal Engenharia Sanitária e Ambiental, covering the environmental integrity of valley floors, and applying a methodology for proposing sustainability indicators in two urban rivers of the city of Maringá, PR (PEREIRA, PAREDES, OKAWA, 2018). In 2019, two articles were published in another special edition of REGET: the first is an analysis of drought events (JULIANI, POMPEU, OKAWA, 2019); and the other about erosion control in a valley floor (VALIM; ORIOLI; FREIRE; POMPEU; OKAWA, 2019). In total, up to this date, the group has published 12 papers in journals.

\subsubsection{Published papers in international events}

With regard to international events, the group has published 8 articles from 2014 to 2018, related mainly to urban drainage with insertion of low impact structural measures (LID) even as a computational model (ROVERI; KURODA; OKAWA; SOARES; ITO; KRIGER JUNIOR et al., 2014; ROVERI; KURODA; OKAWA; SOARES; VALLE; ITO; et al., 2014a; ROVERI; LAUTENSCHLAGER; ANDRADE; PEREIRA; JABUR; OKAWA, 2014b; OKAWA; UYENO; GONÇALVES; JABUR, 2017), solid waste management and erosion in valley floors (POLASTRI; PEREIRA; ANGELIS NETO; PAREDES; OKAWA, 2016; UMADA; POLASTRI; SILVA; OKAWA, 2018; PEREIRA; POLASTRI; ZAMUNER; PAREDES; ANGELIS NETO; OKAWA, 2016) and a new research line regarding the multicriteria analysis as subsidy for decision making in basic sanitation problems (OKAWA; UYENO; GONÇALVES; JABUR, 2018). 


\subsubsection{Published papers in national events}

In national events, the GIAU has published 28 articles, covering topics as: sustainable cities (VALLE; OKAWA; MARTINS; MIOTTO, 2016; RAMOS; SILVA; MIOTTO; CHICATI; OKAWA, 2017), computational modelling of urban drainage systems and insertion of low impact measures (GARCIA; JABUR; ANDRADE; MARQUES; ILDEFONSO; OKAWA, 2015), hydrological studies of flow regionalization in rivers without available data (VIEIRA; ALBERTIN; TRACl; MELO; DORE; OKAWA, 2016; VIDOTTI; VIEIRA; TRACl; ALBERTIN; BENILE. OKAWA, 2016), hydrological studies of drought severity-durationfrequency curves (JULIANI, OWAKA, JAYASURYIA, 2016), studies of outflow permission grant in the state of Paraná (OKAWA; SIQUEIRA; HOJO. MELO; VIEIRA, 2016; JULIANI; POMPEU; VIEIRA; OKAWA, 2018), diagnosis of environmental impacts in valley floors inserted in urban areas (SANCHES; SIMONI; POLASTRI; PAREDES; OKAWA, 2016; POLASTRI; JULIANI; ARAÚJO; BELINE; OKAWA, 2017; ZAMUNER; BENATTI; JULIANI; OKAWA, 2017; PEREIRA; OKAWA; OLIVEIRA, 2018; ALBUQUERQUE; BASSACO; ALBUQUERQUE; BELINE; FERREIRA; BOSSO et al., 2019), urban solid waste management (GASQUES; OKAWA; ANGELIS NETO; ZOLA; SILVA; CASTRO, 2016; PEREIRA; OKAWA; BUENO, 2018; CORREIA; GASQUES; GASQUES; OKAWA, 2019), water resources management, water basins committees and public policies (OWAKA; SCANDELAI; JULIANI; GASQUES, 2017; SANTOS; GASQUES; HOJO; OKAWA, 2018), smart cities and urban water management (GASQUES; ARAÚJO; OKAWA, 2017; NAKAHASHI; RODRIGUES JUNIOR; GASQUES; SANTOS; OKAWA, 2018, NAKAHASHI; CAMILO; OKAWA, 2019), environmental education applied in society (PINHEIRO; SANCHES; PEREIRA; PAREDES; OKAWA, 2015; CARMO FILHO; FURTADO; GASQUES; SANTOS; JULIANI; CORREIA et al., 2017), discussion regarding the difficulties of accessibility during small urban floods (JABUR; OKAWA; RIBEIRO, 2018), proposal of measures for loss reduction in potable water distribution systems (GORZONI; PEREIRA; LAUTENSCHLAGER. OKAWA, 2018), a review of concepts about conventional and sustainable urban drainage systems (NAKAHASHI; CAMILO; ALBUQUERQUE; OKAWA, 2019), hydrological studies of stationarity of historical series of precipitation (JULIANI; FERREIRA; OKAWA; ZUFFO, 2019), and the participative management for conflict 
resolution in water resources by a multicriteria analysis (ARAUJO; OKAWA; ZUFFO, 2019).

\subsubsection{Published books and book chapters}

The group has already published three chapters in books and a book of the Fundamentum series, of the State University of Maringá Press (EDUEM). The first chapter was related to water resources management, published in 2014 in the book "Bacias Hidrográficas e Recursos Hídricos", by publisher Interciência. In this chapter were presented basic concepts of water resources management in Brazil following the Federal Law n. 9.433, of January 8, 1997, that instituted the National Water Resources Policie, with a decentralized and participative management model, institution of water basins committees, water resources managements tools and the national system of water resources management. In 2019, other two chapters were published, entitled: "Simplified Municipal Plan of Solid Waste Integrated Management: case study of municipalities of the Piquiri river basin" and "Water resources participative management in watershed area: case study using cognitive mapping", in the book "Bacias Hidrográficas: Estudos Aplicados", by publisher GFM Gráfica e Editora.

In 2017 it was released the book "Sistema Nacional de Gerenciamento de Recursos Hídricos: composição, competências e estruturas", by EDUEM Publisher, as part of the Fundamentum series, in order to assist undergraduate and post-graduate Civil Engineering students of the State University of Maringá.

\subsubsection{Discussion}

It can be noted that the published papers concentrate mostly on national events, which is understandable as the training of human resources in scientific research initiation is one of the main goals of the group. However, the group is consolidating and the increase in number and in quality of the publications both in national and international journals is a target set to be met. Figure 2 shows the number of papers divided into categories of publication. 
Figure 2 - Number of published scientific papers according to specific categories

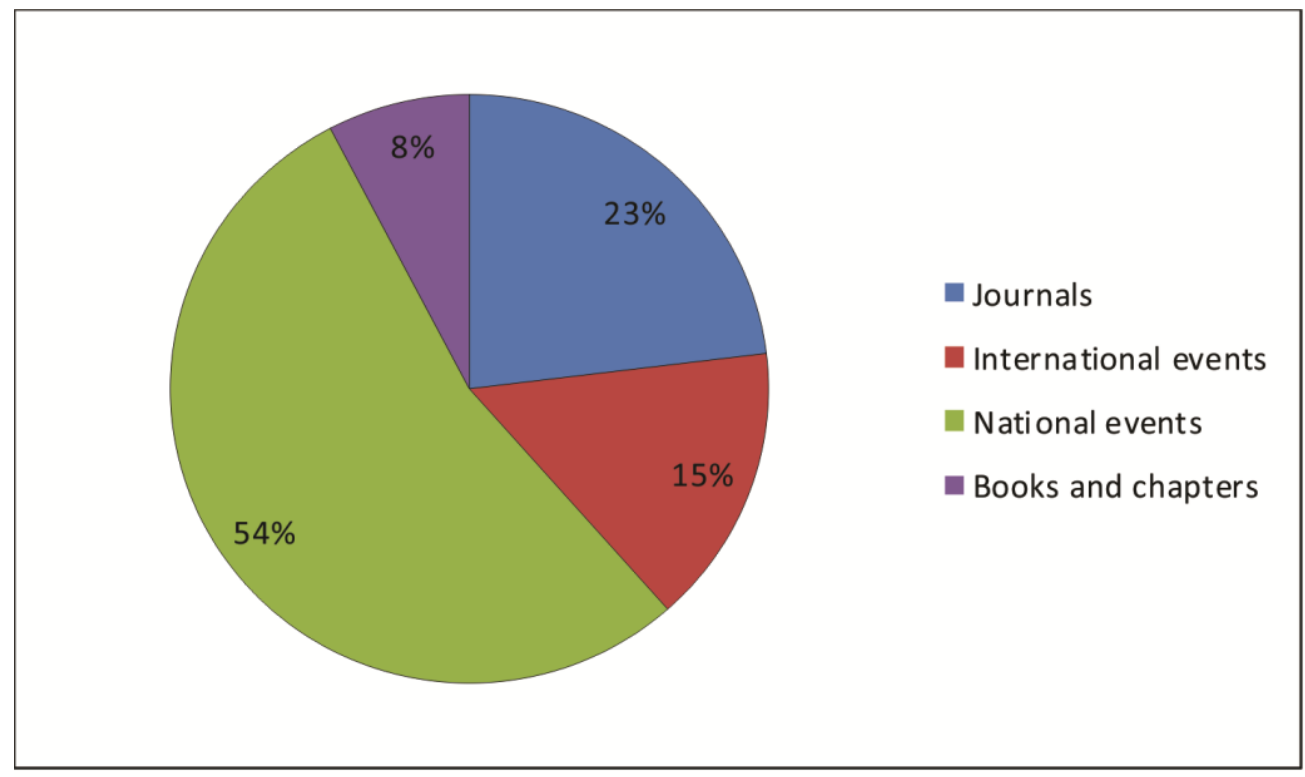

Figure 3 - Number of publications by main topics

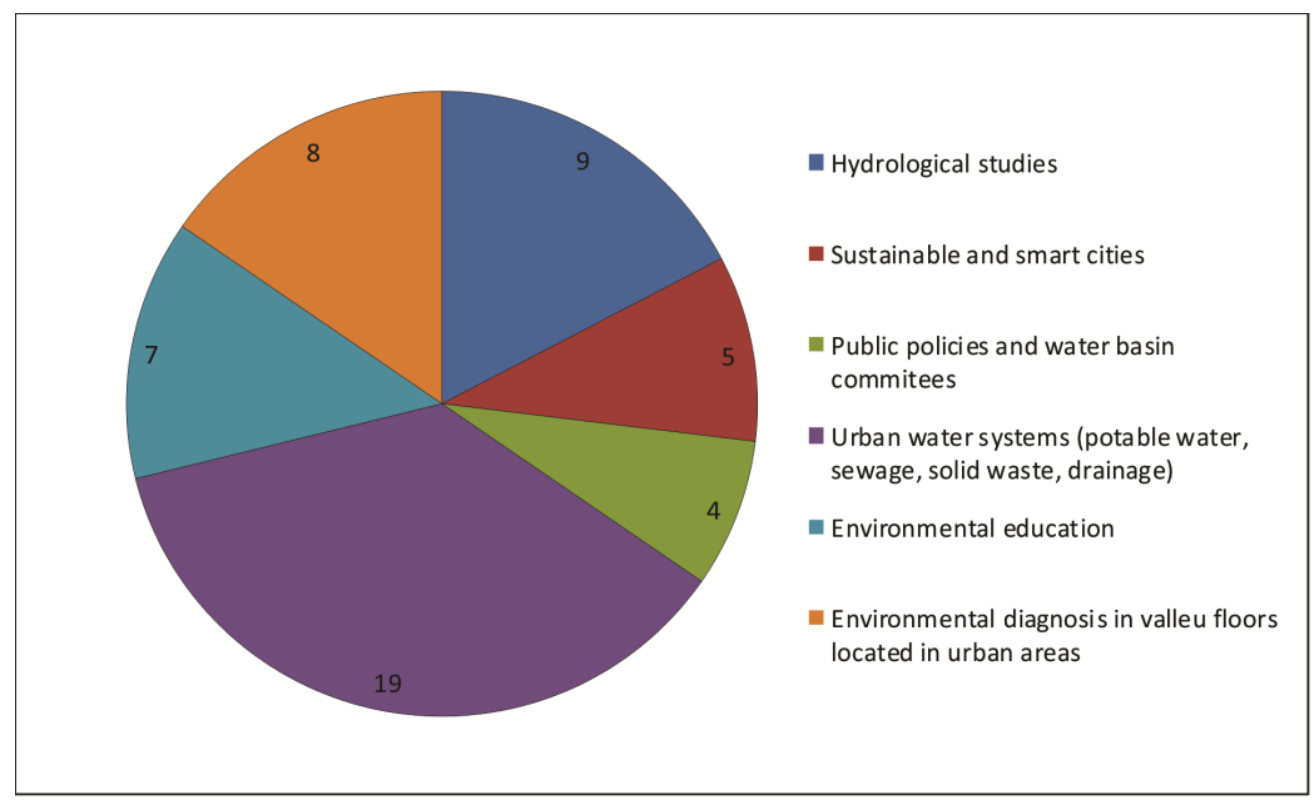

Due to the academic background of the members of the group, que environmental aspects are studied more often and in greater detail, pointing that the group must increase its social network, and also invite professionals from other backgrounds to collaborate in new projects.

The division showed in Figure 3 presents 6 main research topics: hydrological studies; sustainable and smart cities; public policies and water basin committees; 
urban water systems (potable water, sewage, solid waste, drainage); environmental education; and environmental diagnosis in valley floors located in urban areas. Most articles discuss about urban water systems although hydrological studies are also an important group research topic. Environmental diagnosis in valley floors and environmental education are also addressed and must be continually considered.

The number of published works has increased from the year 2014 to 2016, as shown in Figure 4. In 2017, the GIAU coordinator has step aside, for a post-doctorate program, fact that justify the decrease in the number of published articles. Taking that into consideration, in the beginning of 2018 the Breakfast Research meetings were instituted, with the purpose of increased closeness between group members and facilitate the work progress even in the absence of the coordinator. The coordinator has returned to its regular activities in August, 2019, so the number of articles has not increased since 2016, however it was kept constant in 10 papers by year in 2018 and 2019. A few articles are submitted for review and may by published still in 2019 , and others that will probably only be published afterwards. However, it is expected that with the return of the coordinator the number and quality of the papers increase in the following years.

Figure 4 - Publications by year

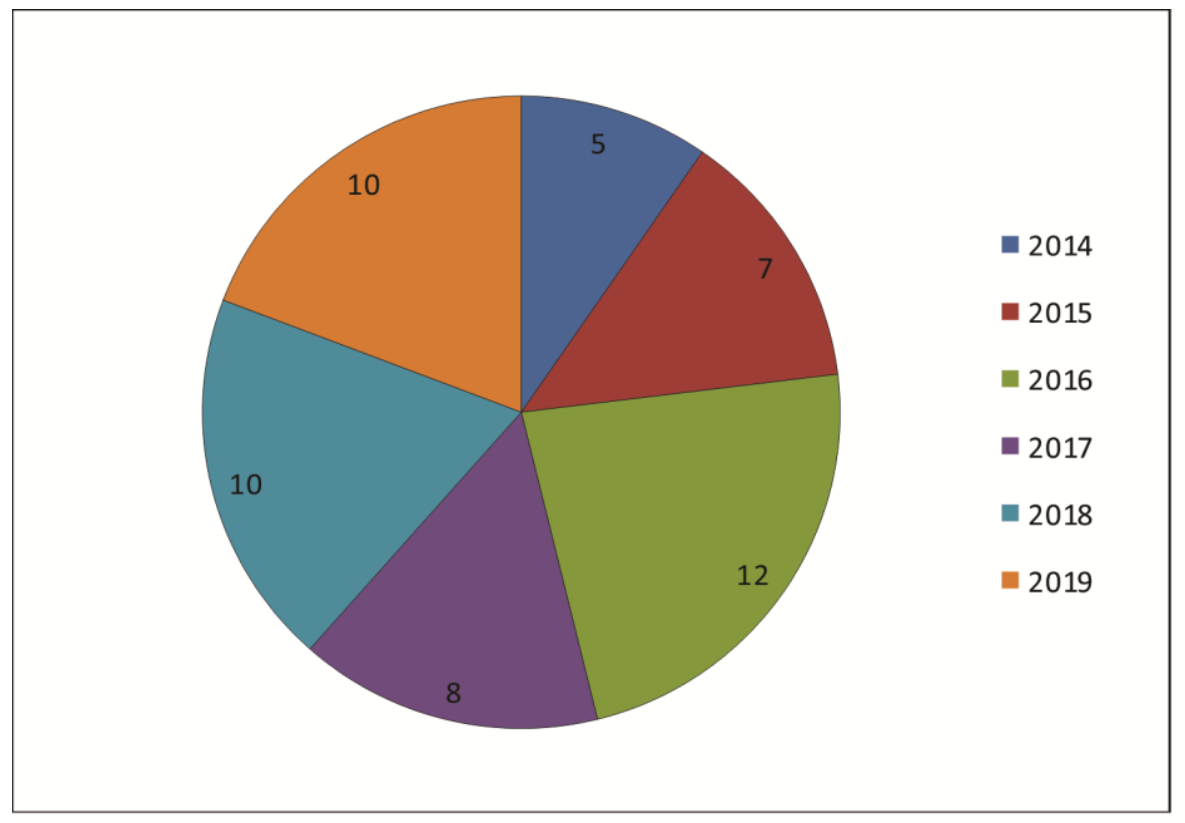




\subsection{Promotion of Events}

The group has promoted two scientific events, denominated "Meeting of Integrated Urban Water Management" (EGIAU). The EGIAU has as objective reunite the academic comunity (undergraduate, master and PhD students, professors and technicians), society, professionals and specialists to exhibit and present papers resulted of research and work experience, as well as debate topics related to integrated urban water management. The importance of this kind of extension event is emphasized since it allows a strong interchange from the Higher Education Institution to the society and to other research institutions from the region, and also a wide discussion about problems and innovative sollutions.

The first EGIAU was carried out in June 30, 2016, in the amphitheater of the State University of Maringá, where 4 lectures were administered with subjects regarding to the integrated urban water management: “Urban Drainage and sediment transport", "Challenges in the potable public water supply", "Urban solid waste management: how to conduct adequate disposal and treatment?" and "Universalization of the sanitary sewage system in Brazil: a challenging perspective". The number of participants were significant for a first edition: 103 participants, including academics, professors, professionals and external community.

The second EGIAU took place in the Apucarana campus of the Federal Technologic University of Paraná, in the dates 14 and 15 of August, 2019 (Figure 5). In this edition, besides the lectures, scientific papers, previously evaluated and accepted for publication, were also presented. The number of participants were also expressive (96 participants), specially to Apucarana be a smaller city than Maringá. The participants were mainly academics of Civil and Chemical Engineering of the university, although a few professionals were also present. Four lectures were presented: "Directives for protection of watersheds in urban areas", "Impacts of inadequate solid waste management in urban waters", "Textile Solid Waste", and "Pollution of Urban Water Bodies - Case study of Jaboti Lake in Apucarana/PR". 
Figure 5 - II EGIAU cover

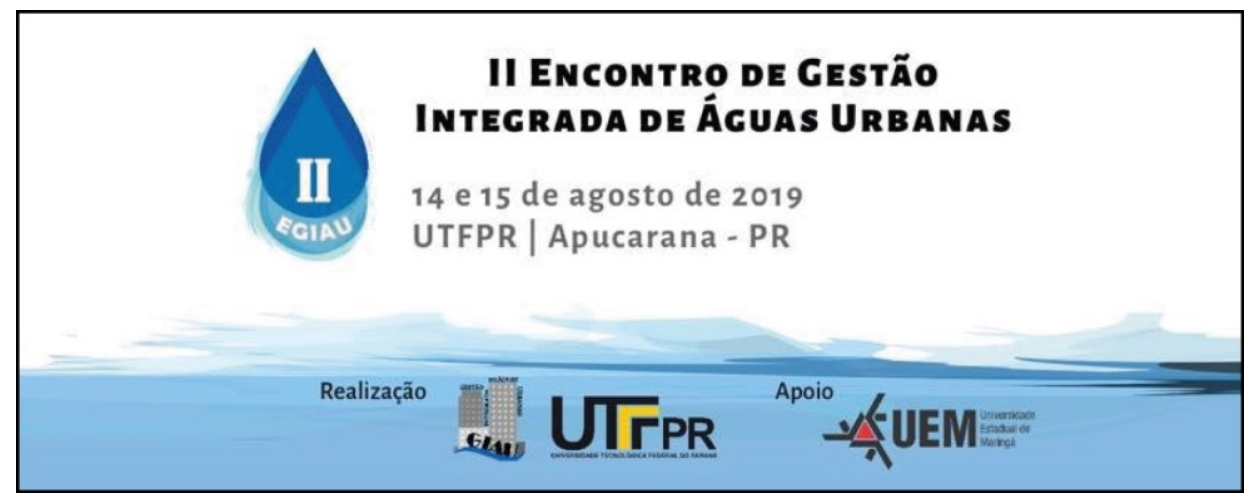

The subject matters proposed for the second edition of the event were: Potable water supply; Sanitary sewage systems and effluent treatment; Reuse of urban and industrial waters; Urban rainwater management; Urban and industrial solid waste; Environmental health; Ecology and urban aquatic ecosystems; Smart cities and innovation; Urban hydrology; Urban water resources management; Georeferencing applied to urban waters; Urban erosion. It is pointed out that not all of the topics were covered in this edition of the event, and the number of submitted papers were small, but considering this being the first time the event opened for submissions and a a small-scale promotion, the event was considered satisfactory. 29 articles were presented in both days of the event, as oral presentations. All of the accepted articles were published in annals and the six best papers were selected by a scientific commission composed by 5 members, who blindly evaluated the papers. These best papers were awarded during the event.

It is intended to keep the subject matters for the next editions of the event, since it is intended a widely promotion to be carried out, reaching other research areas and new researchers with interest in participate. For this regard, a strategy of promotion must be made, with a folder design and other material for the use in social media, along with dissemination in post-graduation programs. As the second edition has been held recently, the website is still active in https://egiau2019.wixsite.com/2019.

It can be noted that although the group has approximately 5 years old since its creation, proactively actions has been carried out in its community by means of 
promotion of lectures and events regarding integrated urban water management. Besides this, the publications of the group members are increasing over time, also in number and in quality, which demonstrate the strengthening of the research group. The next stablished goal is the setting of partnerships with national and international research institutes that operate in the following subjects: integrated urban water management, water resources management, urban hydrology, and another correlated subjects.

\section{CONCLUSIONS}

The GIAU is a research group created in 2014 and has only 5 years of existence. Even so, has has generated 53 publications since its creation, and nowadays presents a group of researchers and professionals with high qualifications and motivated to train human resources and produce a larger number of papers with increased quality in publication.

It can be concluded that the group and its research lines are solidifying, with great future expectations. The subjects covered by the group are actual and important, regarding the whole urban population and the influences in their wellbeing and life quality.

\section{ACKNOWLEDMENTS}

GIAU acknowledges CNPq, CAPES and Araucária Foundation by the scientific initiations and masters sponsorships, which has allowed the undergraduate and postgraduate students to perform their respective researches and to contribute in a significant way for the scientific publications of the group. O GIAU agradece ao CNPq, CAPES e Fundação Araucária pelas bolsas de iniciação científica e de mestrado, o que possibilitou que alunos de graduação e pós-graduação realizassem suas pesquisas e contribuíssem de maneira significativa para as publicações científicas do grupo. 


\section{REFERENCES}

ALBUQUERQUE MB, BASSACO FGS, ALBUQUERQUE RHC, BELINE EL, FERREIRA IA, BOSSO AS et al. Percepção Ambiental no Ribeirão Pinguim, Paraná: Estudo de caso usando Protocolo de Avaliação Rápida (PAR). In: Anais do XXIII Simpósio Brasileiro de Recursos Hidrícos, 2019 nov 24-26, Foz do Iguaçu, Brasil.

ARAÚJO AA, OKAWA CMP, ZUFFO AC. Análise Multicritério de Apoio À Tomada de Decisão Aplicada à Gestão de Recursos Hídricos: Uma Revisão Bibliométrica. In: Anais do XXIII Simpósio Brasileiro De Recursos Hidrícos, 2019 nov 24-26, Foz do Iguaçu, Brasil.

BRANDELER F, GUPTA J, HORDIJK M. Megacities and rivers: Scalar mismatches between urban water management and river basin management. J. of Hidrology. 2019; 573:1067-1074.

CARMO FILHO O, FURTADO CH, GASQUES ACF, SANTOS JD, JULIANI BHT, CORREIA JE et al. Aplicação de Cartilha para Conservação de Fundo de Vale do Ribeirão Morangueiro, Maringá - PR In: Anais do XXII Simpósio Brasileiro De Recursos Hídricos, 2017 nov 26-dez1, Florianópolis, Brasil.

COLE J, SHARVELLE S, GRIGG N, PIVO G, HAUKAAS J. Collaborative, Risk-Informed, Triple Bottom Line, Multi-Criteria Decision Analysis Planning Framework for Integrated Urban Water Management. Water. 2018;10(1722): 1-22.

CORREIA EJ, OKAWA CMP. Plano Municipal Simplificado De Gestão Integrada De Resíduos Sólidos: Estudo De Caso Em Municípios Da Bacia Hidrográfica Do Rio Piquiri. In: Poleto C. (Org.). Bacias Hidrográficas: Estudos Aplicados. Rio de Janeiro: GFM Gráfica \& Editora; 2019. p. 89-112.

CORREIA JE, GASQUES ACF, GASQUES EGF, OKAWA CMP. Gestão De Resíduos Sólidos Urbanos: Análise Do Plano Municipal Simplificado De Gestão Integrada De Resíduos Sólidos Em Um Pequeno Município Do Paraná. In: Anais do VI Simpósio sobre Resíduos Sólidos, 2019 set 11-13, São Carlos, Brasil.

GARCIA C, JABUR AS, ANDRADE FO, MARQUES M, ILDEFONSO JS, OKAWA CMP. Avaliação Da Drenagem Urbana No Entorno Do Parque Florestal Dos Pioneiros. In: Anais do XXI Simpósio Brasileiro de Recursos Hídricos, 2015 nov 22-27 Brasília, Brasil.

GARCIA C, JABUR AS, OKAWA CMP, ILDEFONSO JS. Avaliação Da Drenagem Urbana No Entorno Do Parque Florestal Dos Pioneiros. REGET. 2015;19:3-9.

GARCIA C, MARQUES VR, PEREIRA PP, POMPEU CR, OKAWA CMP, ILDEFONSO JS. Influência Da Configuração Topográfica Na Ocorrência De Alagamentos No Município De Maringá, Paraná. REGET. 2015;19:10-18. 
GASQUES ACF, ARAÚJO AA, OKAWA CMP. Sustentabilidade E Tecnologia Na Gestão Das Águas Urbanas: Uma Breve Revisão De Cidades Inteligentes. In: Anais do $29^{\circ}$ Congresso ABES/FENASAN, 2017 out 2-6, São Paulo, Brasil.

GASQUES ACF, CASTRO TR, GALDINO SJ, ROVERI SD, OKAWA CMP, SILVA JP. Caracterização Dos Pontos De Alagamento Na Cidade De Maringá - Pr: Av. Guaiapó sentido córrego Osório. In: Anais do IX Encontro Tecnológico da Engenharia Civil e Arquitetura, 2013 out 1-3, Maringá, Brasil.

GASQUES ACF, OKAWA CMP, ANGELIS NETO G, ZOLA FC, SILVA JP, CASTRO TR. Identificação de impactos ambientais no gerenciamento de resíduos sólidos urbanos na cidade de Campo Mourão, Paraná In: Anais do III Simpósio sobre Sistemas Sustentáveis, 2016 out 20-21, Porto Alegre, Brasil.

GASQUES ACF, OKAWA CMP, SANTOS JD, GASQUES EGF, DELABIO F. Educação Ambiental: Estudo De Caso Em Dois Colégios Estaduais Da Cidade De Sarandi (PR). Rev. Brasileira de Educação Ambiental (Online). 2016;11:123-138.

GONÇALVES AMB, ROVERI SD, ORIOLI MA, JABUR AS, OKAWA CMP. Diagnóstico Da Rede De Drenagem Urbana De Uma Sub-Bacia Do Córrego Osório, Maringá - PR. REGET. 2015;19:59-66.

GORZONI VAS, PEREIRA PP, LAUTENSCHLAGER S, OKAWA CMP. Medidas Para Redução Das Perdas De Água Na Rede De Distribuição: Estudo De Caso No Município De Altônia, PR. In: Anais do $4^{\circ}$ Simpósio sobre Sistemas Sustentáveis, 2018 maio 21-23, Porto Alegre, Brasil.

JABUR AS, GRANEMANN D, LIMA VAF, OKAWA CMP, GASPARINI RR. Avaliação De Áreas De Riscos De Inundações Na Bacia Hidrográfica Urbana Córrego Fundo, Pato Branco, PR. In: Anais do XX Simpósio Brasileiro de Recursos Hídricos, 2013 nov 17-22, Bento Gonçalves, Brasil.

JABUR AS,OKAWA CMP, RIBEIRO VAS. Dificuldades da Acessibilidade em Pequenas Inundações Urbanas. In: Anais do $4^{\circ}$ Simpósio sobre Sistemas Sustentáveis, 2018 maio 21-23, Porto Alegre, Brasil.

JALILOV S, KEFI M, KUMAR P, MASAGO Y, MISHRA BK. Sustainable Urban Water Management: Application for Integrated Assessment in Southeast Asia. Sustainability. 2018;10(122):1-22.

JULIANI BHT, FERREIRA IA, OKAWA CMP; ZUFFO AC. Estudo De Estacionariedade $\mathrm{Na}$ Série Histórica De Precipitação Da Estação Tibagi, Paraná. In: Anais do XXIII Simpósio Brasileiro de Recursos Hidrícos, 2019 nov 24-26, Foz do Iguaçu, Brasil.

JULIANI BHT, OKAWA CMP; JAYASURYA N. Curvas de Intensidade-Duração-Frequencia para a sub-bacia hidrográfica 56 no estado de Minas Gerais, Brasil. In: Anais do $3^{\circ}$ Simpósio sobre Sistemas Sustentáveis, 2016 out 20-21, Porto Alegre, Brasil. 
JULIANI BHT, POMPEU CR, OKAWA CMP. Drought events analysis and spatial distribution for the states of Rio Grande do Norte and Paraiba, Brazil. REGET. 2019(3).

JULIANI BHT, POMPEU CR, VIEIRA, JV, OKAWA CMP. Curvas De Permanência De Vazões Para Cinco Rios Do Estado Do Paraná: Subsídios Para A Outorga Na Gestão De Recursos Hídricos. In: Anais da $8^{a}$ Reunião de Estudos Ambientais, 2018 maio 21-23, Porto Alegre, Brasil.

KOOP SHA, VAN LEEUWEN CJ. Assessment of the Sustainability of Water Resources Management: A Critical Review of the City Blueprint Approach. Water Resources Management. 2015;29: 5649-5670.

McGRANE SJ. Impacts of urbanisation on hydrological and water quality dynamics, and urban water management: a review. Hydrological Sciences Journal. 2016;26(13):22952311.

NAKAHASHI RT, CAMILO M, ALBUQUERQUE MB, OKAWA CMP. Drenagem Urbana Convencional Versus Drenagem Urbana Sustentável: Breve Revisão De Conceitos. In: Anais do V Simpósio Sobre Sistemas Sustentáveis, 2019 dez 2-3, Porto Alegre, Brasil.

NAKAHASHI RT, CAMILO M, OKAWA CMP. Cidades Inteligentes E O Setor Saneamento: Revisão Sistemática. In: Anais do XXIII Simpósio Brasileiro de Recursos Hídricos, 2019 nov 24-26, Foz do Iguaçu, Brasil.

NAKAHASHI RT, RODRIGUES JUNIOR A, GASQUES ACF, SANTOS, JD, OKAWA CMP. Cidades Inteligentes No Setor Água E Saneamento: Estudo De Caso Na Cidade De Maringá - PR. In: Anais da 8a Reunião de Estudos Ambientais, 2018 maio 21-23, Porto Alegre, Brasil.

OKAWA CMP, DESCOVI CS, SANTOS RB, ZUFFO AC. Classificação De Municípios com Relação à Qualidade Dos Serviços de Abastecimento Público de Água Potável Usando Análise Multicriterial: Bacias Hidrográficas Litoral Norte e Baixada Santista do Estado de São Paulo, Brasil. In: Anais do $8^{\circ}$ Congresso Luso-Brasileiro para o Planeamento Urbano, Regional, Integrado e Sustentável, 2018 out 24-26, Coimbra, Portugal.

OKAWA CMP, HOJO LYCP, MELO ND. Sistema Nacional de Gerenciamento de Recursos Hídricos: composição, competências e estrutura. Maringá: Editora da Universidade Estadual de Maringá; 2017.

OKAWA CMP, NAGASHIMA ES, VIEIRA JV, SOARES PF, MARQUES M, VITAL EPA et al. Determinação Da Vazão De Referência Para O Rio Pirapó Como Subsidio Para O Gerenciamento Do Recurso Hídrico Para Cargas Poluidoras Pontuais. In: Anais do XX Simpósio Brasileiro de Recursos Hídricos, 2013 nov 17-22, Bento Gonçalves, Brasil.

OKAWA CMP, POLETO, C. Gerenciamento de Recursos Hídricos. In: Poleto C. (Org.). Bacias Hidrográficas e Recursos Hídricos. Rio de Janeiro: Interciência; 2014. p. 1-27. 
OKAWA CMP, SCANDELAI APJ, JULIANI BHT, GASQUES ACF, FURTADO CH, CORREIA JE et al. Diagnóstico Da Gestão Participativa Dos Setores No Comitê De Bacia Hidrográfica Do Piraponema. In: Anais do XXII Simpósio Brasileiro De Recursos Hídricos, 2017 nov 26-dez1, Florianópolis, Brasil.

OKAWA CMP, SIQUEIRA RR, HOJO LYCP, MELO ND, VIEIRA JV. Determinação de vazões para outorga de direitos de uso de recursos hídricos: estudo de caso no rio Pirapó. In: Anais do $3^{\circ}$ Simpósio sobre Sistemas Sustentáveis, 2016 out 20-21, Porto Alegre, Brasil.

OKAWA CMP, UYENO MT, GONÇALVES AMB, JABUR AS. Simulation of a drainage network segment in Maringá, Paraná, through the use of SWMM In: Anais da $7^{\text {a }}$ International Conference On Flood Management, 2017 set 5-7, Leeds, Inglaterra.

OKAWA CMP, ZUFFO AC, DESCOVI CS, POLETO C. Gestão Participativa De Recursos Hídricos Em Área De Manancial: Estudo De Caso Usando Mapeamento Cognitivo. In: Poleto C. (Org.). Bacias Hidrográficas: Estudos Aplicados. Rio de Janeiro: GFM Gráfica \& Editora; 2019. p. 201-219.

PEÑA-GUZMÁN CA, MELGAREJO J, LOPEZ-ORTIZ I, MESA DJ. Simulation of Infrastructure Options for Urban Water Management in Two Urban Catchments in Bogotá, Colombia. Water. 2017;9(858):1-16.

PEREIRA LK, OKAWA CMP, BUENO PAA. Disposição De Lixeiras Na Área Comercial Central No Município De Campo Mourão - Pr: Diagnóstico E Análise. In: Anais do $4^{\circ}$ Simpósio sobre Sistemas Sustentáveis, 2018 maio 21-23, Porto Alegre, Brasil.

PEREIRA LK, OKAWA CMP, OLIVEIRA AL. Disposição Inadequada De Resíduos Sólidos Em Córrego Urbano: Um Trabalho De Campo No Município De Janiópolis, Paraná. In: Anais da $8^{a}$ Reunião de Estudos Ambientais, 2018 maio 21-23, Porto Alegre, Brasil.

PEREIRA PP, BERBERT A, SANCHES DM, MARTINS FILHO ST, OKAWA CMP, PAREDES EA et al. Caracterização Física do Córrego Mandacaru, Maringá PR. UNOPAR Científica Ciências Exatas e Tecnológicas. 2014;13:29-34.

PEREIRA PP, PAREDES EA, OKAWA CMP. Diagnóstico preliminar da integridade ambiental de fundos de vale. Eng. Sanit. Ambient. 2018;23(4):739-749.

PEREIRA PP, POLASTRI P, ZAMUNER LD, PAREDES EA, ANGELIS NETO G, OKAWA CMP. Avaliação da erosão e do assoreamento no córrego mandacaru no município de maringá, paraná. In: Anais do $7^{\circ}$ Congresso Luso-Brasileiro para o Planeamento Urbano, Regional, Integrado e Sustentável, 2016 out 5-7, Maceio, Brasil.

PINHEIRO JCG, SANCHES DM, PEREIRA PP, PAREDES EA, OKAWA CMP. Percepção da População Acerca da Operação de Lagoa de Estabilização em Marialva - PR. In: Anais da $5^{\text {a }}$ Reunião de Estudos Ambientais e II Simpósio sobre Sistemas Sustentáveis, 2015 junho 18-19, Porto Alegre, Brasil. 
PIZELLA DG. The relantionship between the Municipal Master Plan and local Watershed Plans in water management. Ambiente e Água. 2015;10(3):635-645.

POLASTRI P, JULIANI BHT, ARAÚJO AA, BELINE EL, OKAWA CMP. Diagnóstico e análise do sistema de descarga de águas pluviais no Córrego Mandacaru em Maringá, Paraná. In: Anais do $29^{\circ}$ Congresso ABES/FENASAN, 2017 out 2-6, São Paulo, Brasil.

POLASTRI P, ORIOLI MA, DA SILVEIRA LWM, OKAWA CMP, PAREDES EA, ANGELIS NETO G. Disposição Inadequada De Resíduos Sólidos Em Fundo De Vale: O Caso Do Córrego Mandacaru. REGET. 2015;9:49-58.

POLASTRI P, PEREIRA PP, ANGELIS NETO G, PAREDES EA, OKAWA CMP. Identificação E Avaliação De Locais De Disposição Inadequada De Resíduos Sólidos Urbanos $\mathrm{Na}$ Cidade De Maringá, Paraná. In: Anais do $7^{\circ}$ Congresso Luso-Brasileiro para o Planeamento Urbano, Regional, Integrado e Sustentável, 2016 out 5-7, Maceio, Brasil.

POMPEU CR, KURODA CY, ALBUQUERQUE RHC, FUSINATO VA, OKAWA CMP. Caracterização De Uma Região Crítica À Erosão Na Cidade De Maringá - PR: Bosque dos Pioneiros. In: Anais do IX Encontro Tecnológico da Engenharia Civil e Arquitetura, 2013 out 1-3, Maringá, Brasil.

RAMOS DV, SILVA JP, MIOTTO JL, CHICATI ML, OKAWA CMP. Estratégias Para A Promoção Da Drenagem Urbana Sustentável Nas Cidades Contemporâneas In: Anais do XXIII Simpósio Brasileiro De Recursos Hídricos, 2019 nov 24-26, Foz do Iguaçu, Brasil.

RICCIARDI RLGF, SOUZA RC, ROVERI SD, OKAWA CMP, ISIRI ML, DUARTE MC. Caracterização Do Fundo De Vale Do Ribeirão Bandeirantes Do Sul Na Cidade De Maringá Pr. In: Anais do IX Encontro Tecnológico da Engenharia Civil e Arquitetura, 2013 out 1-3, Maringá, Brasil.

ROVERI SD, KURODA CY, OKAWA CMP, SOARES DAF, ITO AH, KRIGER JUNIOR LA et al. Aplicação de desenvolvimento de baixo impacto (LID) no dimensionamento de rede de drenagem urbana em um loteamento. In: Anais do $6^{\circ}$ Congresso Luso-Brasileiro para o Planeamento Urbano, Regional, Integrado e Sustentável, 2014 set, Lisboa, Portugal.

ROVERI SD, KURODA CY, OKAWA CMP, SOARES DAF, VALLER RA, ITO AH, et al. Influência da disposição de quadras de um loteamento sobre o dimensionamento da rede de drenagem de águas pluviais. In: Anais do $6^{\circ}$ Congresso Luso-Brasileiro para o Planeamento Urbano, Regional, Integrado e Sustentável, 2014 set, Lisboa, Portugal.

ROVERI SD, LAUTENSCHLAGER SR, ANDRADE FO, PEREIRA O, JABUR AS, OKAWA CMP. Urban Flooding Evaluation For The Osório Creek Sub-Basin Vicinity In The City Os Maringá-PR, Brasil. In: Anais do VI International Conference On Flood Management, 2014 set 16-18, São Paulo, Brasil. 
SANCHES DM, SIMONI JH, POLASTRI P, PAREDES EA, OKAWA CMP. Descrição de impactos no fundo de vale do ribeirão Paiçandu, na cidade de Paiçandu, Paraná. In: Anais do III Simpósio sobre Sistemas Sustentáveis, 2016 out 20-21, Porto Alegre, Brasil.

SANTOS JD, GASQUES ACF, HOJO LYCP, OKAWA CMP. Planejamento E Gestão De Recursos Hídricos no Estado do Paraná: Breve Panorama das Políticas e Programas In: Anais do $4^{\circ}$ Simpósio sobre Sistemas Sustentáveis, 2018 maio 21-23, Porto Alegre, Brasil.

SILVA SMO, SOUZA FILHO FA, CID DAC, AQUINO SHS, XAVIER LCP. Proposta de gestão integrada das águas urbanas como estratégia de promoção da segurança hídrica: o caso de Fortaleza. Engenharia Sanitária e Ambiental. 2019;4(2):239-250.

TUCCI CEM. Inundações urbanas. Porto Alegre: ABRH/RHAMA, 2007.

UMADA MK, POLASTRI P, SILVA OH, OKAWA CMP. Diagnóstico E Análise De Disposição Inadequada De Resíduos Sólidos Urbanos Em Via Periurbana No Município De Sarandi, Estado Do Paraná, Brasil. In: Anais do $8^{\circ}$ Congresso Luso-Brasileiro para o Planeamento Urbano, Regional, Integrado e Sustentável, 2018 out 24-26, Coimbra, Portugal.

UYENO MT, GUIZELINI A, OKAWA CMP. Elaboração De Cartilha Ambiental Como Subsídio Para Sensibilização De Público Infanto-Juvenil. REGET. 2015;19:19-29.

VALIM FA, ORIOLI MA, FREIRE CJA, POMPEU CR, OKAWA CMP. Diagnosis and proposal of erosion control downstream of the Park Alfredo Werner Nyffeler, in Maringá Paraná. REGET. 2019;23.

VALLE RA, OKAWA CMP, MARTINS DN, MIOTTO JL. Cidades sustentáveis: Indicadores de sustentabilidade e a mobilidade urbana In: Anais do V Seminário de Engenharia Civil, 2016 fev 16-19, Maringá, Brasil.

VALLE RA, POMPEU CR, RICCIARDI RLGF, OKAWA CMP, MARTINS DN, PAREDES EA. Uso E Ocupação Do Solo Na Microbacia Do Ribeirão Maringá - Maringá/PR: Análise Da Expansão Urbana Por Meio Do SIG. Revista Tecnológica (UEM). 2016 25:47-56.

VIDOTTI DBM, VIEIRA JV, TRACI DF, ALBERTIN RM, BENLIE EL, OKAWA CMP. Vazão de permanência usando série histórica de vazões e o método de regionalização HG-52: análise comparativa In: Anais do V Seminário de Engenharia Civil, 2016 fev 16-19, Maringá, Brasil.

VIEIRA JV, ALBERTIN RM, TRACI DF, MELO ND, DORE JM, OKAWA CMP. Determinação de vazão de referência por meio do método de regionalização HG-52: estudo de caso rio Carajá. In: Anais do III Simpósio sobre Sistemas Sustentáveis, 2016 out 20-21, Porto Alegre, Brasil. 
VIEIRA JV, LAUTENSCHLAGER SR, ILDEFONSO JS, OKAWA CMP, JABUR AS. As analise de viabilidade para uso de pavimentos permeáveis como dispositivo de controle de escoamento superficial. In: Anais do XX Simpósio Brasileiro de Recursos Hídricos, 2013 nov 17-22, Bento Gonçalves, Brasil.

ZAMUNER LD, BENATTI CT, JULIANI BHT, OKAWA CMP. A Urbanização E O Desenvolvimento De Processos Erosivos Em Área De Preservação Ambiental na Cidade de Maringá, PR. In: Anais do $29^{\circ}$ Congresso ABES/FENASAN, 2017 out 2-6, São Paulo, Brasil.

ZOLA FC, ARAGÃO FV, ZOLA R, OKAWA CMP, ANGELIS NETO G. Wastewater effluent generated by grout industries in Brazil. Journal of Urban and Environmental Engineering. 2016;10(35):35-41.

ZOLA FC, GONZALES BBA, KURODA CY, YANO LT, ROVERI SD, OKAWA CMP. Caracterização Do Fundo De Vale Do Ribeirão Morangueiro Na Cidade De Maringá PR. In: Anais do IX Encontro Tecnológico da Engenharia Civil e Arquitetura, 2013 out 1-3, Maringá, Brasil. 